\title{
Parenting Styles in Relation to Self-Esteem and School Performance of Senior High Students
}

\author{
NARITO M. ARCAY JR. \\ arcaynaritojr@gmail.com \\ https://orcid.org/0000-0002-3468-3159 \\ ROSE MARIE L. CALOPE \\ rmlcalope@universityofbohol.edu.ph \\ https://orcid.org/0000-0002-5759-0529 \\ BUENAVENTURADA D. LIBOT \\ bdlibot@universityofbohol.edu.ph \\ https://orcid.org/0000-0002-9863-2182
}

\begin{abstract}
Parenting styles provide the emotional climate for interaction between parents and children and have significant impact on the family's quality of life. School performance is considered as the adolescents' capacity to interact effectively with the school environment by getting the general point average of their grades in the four quarters of School Year 20182019. This paper examined the effects of parenting styles on self-esteem and school performance among the Senior High students of Tubigon, Bohol, Philippines. The study utilized the descriptive normative survey method of research in gathering data through the use of a standardized survey tool in getting the parenting styles and self-esteem of the respondents. Data mining or desk review was conducted in securing the academic performance of the Senior High School of Tubigon, Bohol. Data were processed using averaging, Freeman Halton Test, Kruskal-Wallis test, and Chi-Square. Majority of the 400 respondents yielded similar results in the four parenting
\end{abstract}


styles, first is authoritative in both mothers ( 52.5 percent) and fathers (46.5 percent). It is followed by the permissive, father (21.5 percent) and mother (17.8 percent). It is followed by ambivalent parenting with fathers (18.8 percent) and mothers (17 percent). The majority (75.5 percent) of the respondents have high self-esteem. Almost a fourth (24.5 percent) had average self-esteem, and no one reflected low self-esteem. Nearly half (45.8 percent) of the total number of respondents had satisfactory school performance, more than a third (36 percent) had an outstanding rating, above a tenth (14 percent) had Very Satisfactory, and very few reflected Fairly Satisfactory (4.3 percent) results. The result of Freeman-Halton test revealed that there is no statistically significant association in the fathers' and mothers' parenting style and the age-groups of the respondents. Chisquare test revealed that parenting styles of both the father $(X 2=7.717$, $d f=3, p<0.10)$ and the mother $(X 2=7.683, d f=3, p<0.05)$ are statistically associated with the sex of the respondents. As to the relationship between self-esteem and academic performance, chi-square revealed a significant result. There is strong evidence of a difference $(p$-value $<0.05)$ between the mean ranks of at least one pair of the indicated categories. There is strong evidence that suggests that parenting styles have some bearing on how students perform at school.

Keywords: Parenting Styles, Self-Esteem, School Performance, Quantitative Method, Tubigon, Bohol, Philippine.

\section{INTRODUCTION}

Parenting Styles across the years of studies have a significant effect on the child and adolescent development. It has been a focus of studies in sociological and psychological perspectives. It is a constellation of attitudes or a pattern of parental authority in dealing with children that most likely can create the emotional context for the expression of parent behavior. Parenting style is defined by a parent-child interaction across settings and situations, (Baumrind, 1971; Darling \& Steinberg, 1993). Parenting provides the emotional climate for interaction between parent and children (Williams, Degnan, Perez-Edgar, Henderson, Rubin, Pine, \& Fox, 2009) and has a significant impact on the family quality of life. Some children who were being raised in various environments can later grow up to have significantly similar personalities. 
Conversely, children who live in the same home and are brought up in a similar environment can grow to have very opposite personalities. In spite of these challenges, researchers have pointed out the links between parenting styles and the effects these styles have on children. As suggested by some, these traits can be carried over into adult behavior.

Undeniably, the parent's upbringing significantly impacts an important life dimension of a child: education. Parenting procedure integrates all the activities of parents that aimed to foster their children's well-being. Various studies in the area of parenting match its importance on the developing person (Shyny, 2017). During the early 1920s, Developmental psychologists have been interested in how parents influence the development of children's social and instrumental competence (NKETSIA, 2013). Parenting continues to linger as the most taxing yet rewarding experience in its perplexing ways.

Parenting style refers to behaviors and possible strategies used by parents to control and socialize their children (Lightfoot, Cole \& Cole, 2009). As pointed out by Gunjan Sharma, Dr. Neelam Pandey, (2015), parenting style defines on parents' moves and the way they manifest their reactions towards their children which covers beliefs they uphold, expectations they set and exhibit values and views on how parents help, support and take good care of the child and how they discipline the child. Set forth by children development professionals, the four parenting styles that are recognized globally: Authoritative, authoritarian, permissive, and neglectful parenting. Deshpande, \& Chhabriya, (2013) posited that parenting style becomes a barometer that indicates parenting functioning and eventually predicts the well-being of a child across a wide array of the environment.

There are two salient elements of good parenting, these are responsiveness (warmth) and demandingness they exhibit on their children (control) which can be merged to generate four categories of parenting: authoritative (high demandingness and high reactivity), authoritarian is defined as high-level demandingness and low-level responsiveness), indulgent or permissive (low level demandingness and low level of responsiveness), and indifferent or neglecting (low level demandingness and low level responsiveness) (Baumrind, 1971; Maccoby \& Martin, 1983). The authoritative parenting is more related to higher levels of adjustment (Steinberg, Mounts, Lamborn, \& Dornbusch,1991), psychosocial maturity (Lamborn, Mounts, Steinberg, and Dornbusch, 1991). 
The term self-esteem is derived originally from a Greek language meaning "reverence for self." The "self" refers to the values, beliefs, and attitudes that we hold on to and the "esteem part implies the value and worth that one gives to oneself." In a nutshell, self-esteem is the way people see themselves at a given time in their lives. In the late 1960s, Rosenberg pointed out that when we talk of high self-esteem, we mean that a person respects and considers himself worthy. Conversely, low selfesteem is the rejection, dissatisfaction, and contempt of oneself. Majority of researchers agree that parental affection or support is positively linked to adolescent (Harper, 1987; Kawas, Peterson, Southworth, and Peters, 1983).

Similarly, a parenting style that neglects the application of guilt, anxiety, and love withdrawal to dominate behavior manifested to have a positive relationship with the self-esteem in adolescents (Graybill, 1987). It is presumed that such action inculcated in them the sense of their inherent value (Openshaw, Thomas, \& Rollins, 1984). A need for a somewhat more ambiguous picture emerges regarding parental discipline that should promote self-esteem (Coopersmith, 1967; Edler, 1963), yet, there is limited empirical support for this hypothesis

There are plenty of studies conducted about self-esteem. Self-esteem is defined as one's assessment of self-worth (Lightfoot, Cole \& Cole, 2009). Branden (1969) suggested that generally, self-esteem is created and altered through an individuals' beliefs and awareness of their thoughts, feelings, and behaviors.

Moreover, self-esteem can be formulated in multiple ways. Selfesteem is considered indispensable to healthy human development. A remarkable humanistic psychologist, Abraham Maslow (1987) consider self-esteem as one of the basic human necessities. In his theory of the hierarchy of needs, esteem comes near the peak.

School performance is one significant aspect that is directly linked to parenting styles. Parents are said to be the first teachers of children. Theories in child development psychology suggested that children mimic and absorbed the teachings and actions of their parents. The way they act and handle themselves mirror the manner they are brought up by their parents. Their performance in school reflects the support they had received. At some point, higher levels of support allow children to perform well in school and make them creative and academic performers. Parenting style, in this sense, had a crucial role in shaping the mental, physical, social, 
emotional, and psychological aspects of a child. One great contributor to a child's intelligence is how parents raised and nourished them.

The Philippine Statistics Authority (2015) came up with an estimate of 20 million adolescents age 10-19. A portion of this immense population is currently enrolled in Senior High School. The K-12 became a law to provide opportunities on the country's increasing number of adolescents who need more knowledge, skills, and training as they transition from young adolescents to adults. The move also prepared the adolescents to become productive members of the society even if they don't enroll in college for they are physically and mentally ready to join the workforce. A study conducted by Viviamo Inc., the company behind Belle de Jour Power Planner on 614 adolescents, revealed that 7 out of 10 adolescents do not have a dream. The principal reasons are due to factors such as low self-esteem and inadequate educational programs.

Tubigon is a first-class municipality in the Province of Bohol, currently, has three public and three private schools, with around 1,624 Senior High Students enrolled. The vast portion of adolescents in the Municipality has its share of academic achievements and struggles. The Municipality is tagged as a well-performing town in the province due to its outstanding performance in the field of arts, education, and economic success. Given the unique location and cultural upbringings, each of the adolescents has its manner of coping with school activities resulting in outstanding school performance. The study sparks interest in how parenting styles affect the adolescent's self-esteem and school performance in the unique and highly competitive Municipality of Tubigon.

Overall, there is a shortage of studies in the topic of parenting in Southeast Asian families, particularly in this country. The result of the study will examine the effects of parenting styles on self-esteem among the Senior High students of Tubigon Bohol for the school year 20182019. This paper will also provide substantial information, as it delved into the impact of the parenting style variable on the adolescent's school performance among the respondents.

Several theoretical underpinnings are considered a framework in this particular study. The researcher looked into the perspectives of Baumrind, Stanley Hall, Erikson, Bromfrembrener, Bandura, among others.

The work of a developmental psychologist, Diana Baumrind (1966) is noteworthy to mention, who conceptualized several styles of parenting that focused on people's approach to parenting rooted in parents' demands of 
their children. Further, it looked into how responsive these parents are on their children's needs. Hence, the theory pinpointed on three primary parenting styles, authoritative, authoritarian and permissive.

Storm and stress theory. As pointed by Anna Freud, to be considered normal at the adolescent period is by itself considered abnormal. The "storm and stress" phrase that was coined by G. Stanley Hall in 1905 encapsulated the concept that young people are like emotional volcanoes ready to explode. Hall posited in his 1904 book, that storm and stress was an inevitable part of adolescent development. His storm and stress hypothesis refers to the decreased self-control seen in adolescents (the "storm" part of the hypothesis) versus the increased sensitivity in adolescents to various arousing stimuli around them (the "stress"). As suggested by Hall, storm and stress influenced adolescent behavior in three fundamental ways: Conflict with parents in such a way that adolescents begin to challenge the wisdom of the elder, Mood disruptions that are manifested by regular mood swings and Risky behavior in which they resort to smoking or drinking and may eventually commit a criminal act. In the years that followed, researchers and people in the academe have made their presumption on Hall's developmental hypothesis and whether the adolescent conflict was due to familial or biological factors (Arnett, 1999).

Social Learning Theory. Bandura (1963) stated that behavior is a result of cognitive and environmental factors interplaying with each other. In the social learning framework, new examples of conduct can be obtained to coordinate involvement or by watching the practices of others. The Social-Learning theory revolved around a person's vain inclinations and put into consideration those ecological components that impact a person's conduct. The theory expresses that adolescents imitate a considerable amount of things that they see and hear around them; smoking, drinking, and sex. Social Learning theory is considered to be the basis of socialization process (Spilka, Hood, Hunsberger, \& Gorsuch, 2003). Moreover, the theory also suggested that individuals learn essentially through perception and reward and punishment. Generally, actions of the young people are robustly impacted by the demonstration of others in their social environment.

Ecological Theory. Urie Bronfenbrenner underscored the importance of studying a child in the context of the diverse environment. He organized the context of a child's development into five levels of external influence. Among the levels, the most proximal context in the world of adolescents is 
the microsystem which comprises the daily home, school, peer group, and the community group. It further posited that the adolescents' behaviors are exhibited in the context of their relationships with significant others in the context of their ecological milieus (Pilongo, Aparece, \& Tirol, 2013).

One of the goals emphasized by the Sustainable Development Goals (SDG) is to sustain healthy and well-functioning families as it is the primary backbone in creating a supportive and safe environment upon which children can thrive and achieve positive outcomes. This scenario is highlighted in SDG 3 as it emphasized the importance of "Ensuring healthy lives and promote wellbeing for all at all ages.

Many families experience challenges in providing a positive environment. Conversely, societal trends can also affect the nature of the family circumstances, and the social/financial supports for families in their task of parenting and supporting children's wellbeing. As emphasized by Kamerman and Kahn (1978) four decades ago - and Robila (2014) and Bogenschneider (2006), family policies can be widely understood as government activities that are intended to support families and enhance the well-being of family members, and to strengthen family relationships.

The United Nations Convention on the Rights of the Child (UNCRC) defined the specific rights and guidelines for upholding the rights of children. Such is a legally-binding international agreement setting out the civil, political, economic, social, and cultural rights of every child, regardless of their race, religion, or abilities. The UNCRC consists of 54 articles that set out children's rights and how governments should work together to make them available to all children. Under the terms of the convention, governments are required to meet children's basic needs and help them reach their full potential. Central to this is the acknowledgment that every child has basic fundamental rights".

The idea regarding parenting styles first emerged during 1970 and was initially observed by Diana Baumrind, a developmental psychologist. "The parenting styles mean as the strategies and behaviors utilized by parents to socialize and control their children" (Lightfoot, Cole \& Cole, 2009). During 1983, two notable researchers, Maccoby and Martin reevaluate the three styles. They reassessed the findings of Baumrind and had added two measures, such as demandingness and responsiveness. As shown by their findings, there appeared to be more parenting styles than previously presented. They eventually ended up separating the permissive style and formulated two different parenting techniques that 
suit their results when considering observed levels of responsiveness and demandingness. As a result, both studies have developed the permissive and neglecting terms that apply to these parenting styles. Henceforth, four parenting styles have been recognized globally, and authoritative parenting means a high level on demandingness and so with their responsiveness. The authoritarian type is defined as a high level of demandingness, but low level of responsiveness whereas permissive type means low on demandingness but high on responsiveness. Lastly, neglecting parenting style exhibits low in both demandingness and responsiveness (Maccoby \& Martin, 1983).

A remarkable psychologist, John $\mathrm{R}$. Buri created parental authority questionnaire (PAQ) to evaluate the parenting styles conceptualized by Baumrind, (1966), permissive, authoritarian, and authoritative comprising 30 Likert type items. The tripartite typology has three sub-dimensions. For Authoritative ( Factor 1: Warmth and Involvement, Factor 2: Reasoning/ Induction, Factor 3: Democratic Participation, Factor 4: Good Natured/ Easy Going), for Authoritarian (Factor 1: Verbal hostility, Factor 2: Corporal punishment, Factor 3: Non-reasoning, punitive strategies Factor 4: Directiveness), and on Permissive (Factor 1: Lack of follow-through, Factor 2: Ignoring misbehavior, Factor 3: Self-confidence). The subjects (children) need to respond to the thirty-item examination of each parent on a five-point scale. Steinberg, Lamborn, Darling, Mounts, \& Dornbusch, (1994), generated authoritative parenting scale to measure the level of the authoritativeness of the parents on three major dimensions: acceptance/ involvement, firm control, and psychological autonomy granting. The 36 item scale measure parenting styles in the viewpoint of a child on three dimensions. Moreover, Alpha coefficient of the dimensions ranged between 0.72 and 0.76 .

Few years after, a research conducted by Steinberg et al., (1994) underpinned the four-dimension typology and had looked into possible effects that parenting styles pose on children. Findings of their study showed that children with authoritative parents were more competent in contrast to children coming from another parenting style in terms of social, emotional, and academic abilities. Those children whose parents practiced authoritarian parenting were found to have lower levels of wellbeing than children who grew up with other style and children with indulgent parents had high levels of wellbeing but lower levels of achievement. Furthermore, children with neglectful parents manifested the lowest levels in all areas. 
The results implied an exact link between parenting styles and personality traits of children. Similar results have generated in the studies on Grusec, \& Goodnow, (1994) and Pomerantz, Grolnick, \& Price, (2005). They stressed that children from authoritative parents had greater proficient social, skills, independent problem solving, psychological wellbeing, and adjustment, contrary to children reared by other parental styles.

In the year 2012, a study revealed that the environment where children are raised contributes significantly to the development of children's selfesteem (Hosogi, Okada, Fujii, Noguchi, \& Watanabe, 2012). This goes to show that everything from school and family dynamics to socioeconomic status and the parenting styles, profoundly impacted the child. Another study implied deeply that nurturing and supportive parenting styles would improve children's self-esteem (Yang \& Lian, 2008). DeHart et al., 2006) contend that research anchored on specific parenting styles concluded that parenting styles directly affect the child's self-esteem. Several research studies produced different results as to what parenting style leads to the highest level of self-esteem. In the study of Martinez and Garcia during 2007 showed that children who were raised by indulgent parents possessed the highest level of self-esteem while those with authoritarian parents had the lowest. Martinez et al. (2007) concluded that authoritative and indulgent parenting styles scored highest on levels of self-esteem. A year after, another study spearheaded by Martinez and Garcia (2008) uncovered indulgent parenting provided by parents to adolescents had equal or higher levels of self-esteem compared to adolescents with authoritative parents. The research further unveiled that adolescents with authoritarian and neglectful parents had the lowest level of self-esteem. On the other hand, studies of Garcia and Gracia (2009) showed that both indulgent and authoritative parenting styles had yielded the highest selfesteem among children.

In 2012, a study conducted by Antonopoulou, Alexopoulos, \& MaridakiKassotaki, (2012), pointed out the quality of supportiveness as perceived by the child had predicted higher levels of implicit self-esteem, and children with neglecting parents would have lower levels of self-esteem. DeHart, Pelham, \& Tennen, (2006), maintained that parents who were deemed more nurturing (authoritative and permissive) had a positive effect on self-esteem while the parented view to be authoritarian had a negative effect. Parenting styles that were authoritative and permissive have been correlated with higher levels of self-esteem while negative, loving, anger, 
and rejecting were negatively correlated (Yang \& Zhou, 2008). It was maintained that, in considering the effects on self-esteem, it is essential to look at the potential changes in self-esteem overtime for the studies were only examined in a single period.

Over time, studies conducted concerning self-esteem produced different outcomes. One intriguing finding claimed that self-esteem increased throughout adolescence to middle adulthood, where it begins to decrease as one enters old age (Orth, Robins, \& Widaman, 2012). It is necessary to put into consideration confounding factors within these results, like success in one's 'hosen endeavor or family life or deterioration of health (Orth, Trzesniewski, \& Robins, 2010). The results may somehow be attributed to the accomplishment of age-specific challenges such as finishing levels of school, marriage children, physical complication, retirement or illness (Wagner, Lüdtke, Jonkmann, \& Trautwein, 2012). One study affirmed the conclusion that self-esteem increased throughout adolescence and added that the gender variable does not affect the adolescence period (Erol \& Orth, 2011). However, it is essential to consider the impact of gender because the past study did not include gender as a variable of interest. Solely, the adolescence stage showed a general increase in self-esteem as what is exhibited by the results (Orth et al., 2012). It is vital to assess possible variables influencing the increase in self-esteem during adolescence. Accordingly, one variable that was found to have a significant effect is that, as one's education level increases, selfesteem also rises (Hallsten, Rudman, \& Gustavsson, 2012). Citing factors that influence self-esteem and how it changes as years go by, it is also important to note that parenting styles could also change over time. This is to say that parenting styles could have positive or negative effects on the child's self-esteem levels through time and development.

The value of parenting style could increase if discipline or education is the focus on the child or decrease if a child's main concern would be placed sensitivity or responsiveness. It will stay the same in the preschool stage if the focus is on general welfare and protection. Later on, parenting styles decrease as the child enters late adolescence and early adulthood (Wentzel, 1994). This implies that parenting style should change as the child grow. It has also been found that inconsistent parenting may lead to aggressive and rebellious behavior (Lightfoot, C., Cole, M., Cole, S., 2009). Other studies have explained that for a particular age and generation, responsiveness and sensitivity are two outstanding qualities 
that parents' should possess for a child's development while disciplinary qualities are least valuable when trying to rear a happy and productive child (Shamah, 2011). As the conclusion of these findings, perhaps, there could be a singular parenting style that works across all ages.

A study by Dornbusch, Ritter, Leiderman, Roberts, \& Fraleigh, (1987), explored the relationship between child-reported parent style, using adolescent achievement and Baumrind's typology. Findings of this study indicated that reports on lower grades were associated with more authoritarian, more permissive, and less authoritative parenting. Although this study used students' objective indices of school performance only and parental behavior report of students, it highlighted the importance of the styles of parenting to school-related competence. In the latest study of parenting styles relevance to the academic domain, it was built upon previous work by attempting to differentiate between autonomy versus control orientations and firm versus lax parental control. We conceptualized two distinct, separable dimensions, namely, structure and autonomy support. Autonomy support means the degree to which parents value and use techniques that encourage autonomous ways of solving problems, arriving at sound choices, and participation in decisions versus externally dictating outcomes, and motivating achievement through corporal, disciplinary methods, pressure, or ways of controlling rewards. The structure, in contrast, was defined as the extent to which parents provide clear and consistent guidelines, expectations, and rules for child behaviors, without respect to the style in which they are promoted.

A study emerged and reconstructed Baumrind's typology of the parenting style in the aspect of adolescent's school performance. Using a broad and manifold sample in San Francisco Bay Area High school students $(\mathrm{N}=7836)$, it was unveiled that both authoritarian and permissive parenting practice was positively connected to with grades. The results unfolded that parenting styles presented an expected relation to grades across gender, age, parental education, race, ethnics, and family structure categories. It was furthered revealed that Authoritarian parenting had a stronger link with grades compared to the two other parenting styles except to Hispanic males - all the styles best indicated among white students. As claimed, pure authoritative families (high on authoritative but low in two indices) had the highest mean grades, while inconsistent families, the merged authoritarian parenting with other parenting styles yielded the lowest grades. 
As claimed by Leung, Lau, \& Lam, (1998), the relationship between four parenting styles and academic achievement in school children was investigated in Hongkong, the United States, and Australia. Results indicated that Australian parents were lower than both Chinese and American parents in academic authoritarianism. Compared to the two English-speaking groups, Chinese parents were higher in general authoritarianism, but lower in academic and general authoritativeness. In all these cultures, academic achievement was negatively related to academic authoritarianism but showed no relationship with academic authoritativeness. Finally, In Hongkong, the United States and Australia, academic achievement among children was directly related to general authoritarianism, the parents of those children did not have any college education. Academic achievement was positively related to general authoritativeness only in the two English-speaking groups.

Glasgow, Dornbusch, Troyer, Steinberg, \& Ritter, 1997 presupposed, in their article, the contemporaneous and predictive relations between styles of parenting, adolescents' attributions, and four educational outcomes. Data were collected in 1987-1988 and 1988-1989 School Years from adolescents attending six high schools in California and three high schools in Wisconsin. The path analyses results partially confirmed the central hypotheses that adolescents who perceived their parents to be nonauthoritative were more likely than their peers to attribute achievement outcomes to external causes, or low ability. Also, the higher the proportion of attributions due to dysfunctions were evident for academic successes and failures. It was also found in the study that the lower the levels of classroom engagement and homework a year later. Even though adolescents' attributional style provided a bridge between parenting style and two outcomes of education, it did not explain the results of parenting on those instances fully.

A study on the relationship between parenting styles and academic achievement among students showed that there was a significant positive relationship between the emotional atmosphere of the family, declining to the principles of democracy and creativity (Mehrafza, 2004). The study further presented that there was a significant negative relationship between the creativity and authoritarian parenting, and there was no statistically significant relationship between the emotional atmosphere of the family, declining to absolute freedom and creativity. In a study on the relationship between motivations and education achievements 
on high school students of Isfahan and their family characteristics, the results explained that from among the factors linked to educational performance, authoritarian parenting style and family composition pointed out achievement motivation (Abedi, Aarizi, Sobhaninejad, 2005). Another study examined the relationship between self-esteem, and educational achievement among high school students in Tehran found out that there was a significant correlation between self-esteem and educational achievement (Biabangard, 2005).

In the study of Kordi and Baharudin (2010), unveiled that among the parenting styles, authoritative style is a nexus to higher levels of children's school achievement. In the same theme, a study conducted by Bacus (2014) regarding parenting styles and academic performance, showed that in Mindanao, authoritative parenting was the dominant parenting style commonly practiced by families. It was viewed as a robust way of disciplining to shape a successful child. On the other hand, to cope with the fast-changing world, some children were reportedly raised by permissive parents. In this case, children were left to do with much freedom whatever they like to do. It was found out in the study that the respondents reported a positive response to learning as they showed manifestations of liking their school, teachers, and schoolwork. Authoritative style was revealed as the significant parenting style strongly linked to academic performance. On the study entitled "Examination of the relationship of parenting styles and attitudes with creativity and its relationship with intelligence, educational achievement and progressive behaviors" carried out in Ahvaz, found out that there was a negative correlation between the various parenting styles and academic performance.

Another study revealed that authoritative is the most practiced style received by adolescents. Furthermore, It was claimed that children are more robust in handling situations and showed a significant relationship between parenting styles and self-esteem of adolescents (Rodrigues, Veiga, Fuentes, \& García, 2013). Dalisay (2014) in a study, examined the parenting styles and self-esteem among criminology students of Lyceum of the Philippines uncovered that majority of the respondents commonly have authoritative parents and showed moderate and high-level of selfesteem. The study of Gilongos and Guarin (2013), employed surveyquestionnaires, interviews, and focus groups to examine the relationship between parenting styles and social adjustments of school-age children in Aklan manifested similar patterns. Authoritative parenting styles reigned 
supreme and was deemed as their healthy relationship with parents and peers.

A similar study that used survey-questionnaire carried out in Northern-Samar based high school students that investigate the relationship between parenting styles showed authoritative parenting as the dominant style in which most of the students exhibited energeticfriendly behavior. However, he found no connection between parenting styles and students performance.

The primary aim of the study was to determine the relationship of parenting style to self- esteem and school performance of Senior High Students of Tubigon Bohol during the school year 2018- 2019. The findings of the study woud serve as basis for the recommendation.

Specifically, it sought to answer the following queries:

1. What is the level of parenting styles as perceived by the studentrespondents in the following dimensions:

1.1 Authoritative;

1.2 Authoritarian;

1.3 Permissive;

2. What is the level of self-esteem of the respondents?

3. What is the level of school performance of the respondents?

4. Is there a significant degree of relationship between the profile of respondents and their level of parenting styles?

5. Is there a significant degree of relationship between profile of respondents and their level of self-esteems?

6 . Is there a significant correlation between parenting styles (mother and father) and self-esteem of the respondents?

7. Is there a significant correlation between parenting styles (father and mother parenting styles) and academic performance?

8. Is there a significant degree of variance on the self-esteem of the respondents when they are grouped according to parenting styles?

9. Is there a significant degree of variance in the academic performance of the respondents when they are grouped according to parenting styles? 
10. What recommendations can be proposed based upon the findings of the study?

Null Hypotheses. The study was directed toward the acceptance or rejection of the following null hypotheses:

1. There is no significant degree of relationship between profile of respondents and their level of parenting styles.

2. There is no significant degree of relationship between profile of respondents and their level of self-esteem.

3. There is no significant correlation between parenting styles (mother and father) and self-esteem of the respondents.

4. There is no significant correlation between parenting styles (father and mother parenting styles) and academic performance.

5. There is no significant degree of variance on the self-esteem of the respondents when they are grouped according to parenting styles.

6. There is no significant degree of variance in the academic performance of the respondents when they are grouped according to parenting styles.

\section{RESEARCH METHODOLOGY}

Design. The study utilized the descriptive normative survey method of research in gathering data through the use of a standardized survey tool in getting the profile of the respondents and their responses on their experienced parenting styles and self-esteem.

Data mining or desk review will be conducted secure the academic performance of the Senior High School respondents from various schools.

Respondents. The study was carried out in six private and public Senior High institutions in the municipality of Tubigon, Bohol, particularly the schools of Mater Dei College, Tubigon West Central High School, Tubigon West National High School, Cawayanan National High School, Saluz Institute of Technology, and Holy Family of Nazareth. A total of 200 male respondents and 200 female respondents were the subjects of the study. Equal distribution of respondents was also considered to make sure that both and public schools are equally represented. 
Instrument. The measures included indices of parenting style as well as indices of self-esteem. The following specific measures were analyzed using the following: The study utilized the Parental Authority Questionnaire that was created by Buri (1989) to measure parental authority or disciplinary practices from the perspectives of children at any age. PAQ consisted of 30 items that have three subscales based on the parental authority prototypes, and each subscale consist of 10 items (Ang \& Goh, 2006). There is permissive (P: items 1,6,10,13,14,17,18,19,21\&24), The Authoritarian items (A: items 2,3,7,9,12,16,18,25,26\&29) and Authoritative items ( $\mathrm{T}$ : items 4,5,8,11,15,20,22,23,27\&30). Respondents were asked to respond to each item on a 4 point Likert scales that ranged from strongly disagree (scored 1) to strongly agree (scored 4) that will best describe how that statement would appy to participants and their parents (Dwairy \& Menshar, 2006). Buri (1989) originally created the tool and the paper was presented at the Annual Meeting of the Midwestern Psychological Association.

Rosenberg self-esteem scale was created by Morris Rosenberg in 1965 and has been widely used in various studies worldwide today. It measures global feelings of self-worth and for use with adult populations. RSE has high internal reliability, which is .92 and strong construct validity. It consists of 10 items that examine rate on a five-point scale from strongly agree (scored 4) to 16 strongly disagree (scored 0) (Kaplan \& Saccuzzo, 2008).

Scoring: The PAQ was calculated by adding the individual items within each subscale. Higher scores signified a greater level of the specific parenting style (Ang \& Goh, 2006). The RSE had a possible total score ranging from $0-40$. The higher scores corresponded to higher levels of self-esteem. The RSE was calculated by adding scores on each item. There was a reverse order scoring of items 2,5,6,8 and 9 .

\section{School Performance}

The school performance school determined by taking the General Point Average (GPA) of the respondents of the Calendar Year 2018-2019.

The GPAs were analyzed using the corresponding scale:

\begin{tabular}{|l|c|c|}
\hline Descriptors & Grading Scale & Remarks \\
\hline Outstanding & $90-100$ & Passed \\
\hline Very Satisfactory & $85-89$ & Passed \\
\hline
\end{tabular}




\begin{tabular}{|l|c|c|}
\hline Satisfactory & $80-84$ & Passed \\
\hline Fairly Satisfactory & $75-79$ & Passed \\
\hline Did not Meet Expectations & Below 75 & Failed \\
\hline
\end{tabular}

The researchers explained the objectives in the letter of consent sent to the respondents. They were briefed that the rights will be respected from start to finish the research. Assurance of complete anonymity of the respondents was upheld. They can stop at any point in answering if they feel the rights are violated. As a sign of consent, they affixed their signature. Complete anonymity was observed the handling of the data. Such data were submitted to the University Research Center for the observance of archiving and further handling of the complete anonymity of such.

The data underwent normality test to ensure that the right statistical procedures will be carried out using the Statistical Package for Social Science (SPSS V25) as it is one of the concrete measures of checking the validity to draw out concrete and reliable findings and interpretations. It utilized Shapiro-Wilk as the number of samples was less than 2000. All data yielded from significant to highly significant results in the computation. In this vein, non-parametric measures were used on the statistical treatments of data.

\section{RESULTS AND DISCUSSION}

\section{Levels of Parenting Styles}

The table 1 illustrates the analysis of the Parenting Styles according to four types, namely, Authoritarian, Permissive, Authoritative/Flexible, and Ambivalent. This type of data processing and interpretation is based identification on the dominant parenting style for each of the respondents by Lee 2011, utilizing the method used in his study on Relationship Between Parenting Styles and Self-Esteem. The parenting style with the highest sum is the dominant parenting style, which can then be distributed by percentages. The problem with the second method is that, more too often, there are ties in scores. For example, there are instances when scores in all three parenting styles are the same. This means that it cannot identify which parenting style is dominant. The problem of ties was addressed by creating a new category, which is the Ambivalent Parenting. Thus, the number of categories increased from three to four, namely: permissive, authoritarian, authoritative/flexible, and ambivalent. Further, Some 
research studies found an ambivalent parenting style among parents that is a mix of the authoritarian and permissive styles (Al-Mutlaq, 1981).

Table 1. Parenting Styles of mothers and fathers as perceived by the respondents

\begin{tabular}{|c|c|c|c|c|}
\hline \multirow{2}{*}{$\begin{array}{l}\text { Parenting style of } \\
\text { respondents' parents }\end{array}$} & \multicolumn{2}{|l|}{ Father } & \multicolumn{2}{|l|}{ Mother } \\
\hline & Frequency & Percent & Frequency & Percent \\
\hline Authoritarian & 53 & 13.3 & 51 & 12.8 \\
\hline Permissive & 86 & 21.5 & 71 & 17.8 \\
\hline Authoritative/Flexible & 186 & 46.5 & 210 & 52.5 \\
\hline Ambivalent & 75 & 18.8 & 68 & 17.0 \\
\hline Total & 400 & 100.0 & 400 & 100.0 \\
\hline
\end{tabular}

As shown in Table 1, data reveals that majority (52.5 percent) among the respondents claimed that they experienced authoritative parenting from their mothers, whereas, less than half ( 46.5 percent) said so about the parenting styles of their fathers.

It is followed by Permissive Type of Parenting upon which above a fifth (21.5 percent) from their fathers' compared to that type of parenting from their mothers' (17.8 percent).

Almost a fifth experienced ambivalent parenting, which respondents claimed a little higher of their fathers' parenting style (18.8 percent) compared to that of their mothers' (17 percent).

\section{Levels of Self-Esteem of the Respondents.}

Table 2 provides a clear picture of the Self-Esteem utilizing the scoring and interpretation of the Rosenberg Self-Esteem Scale, 1965).

Table 2. Level of Self-Esteem of the Respondents (Using Rosenberg's Scoring)

\begin{tabular}{|c|c|c|}
\hline Level of self-esteem & Frequency & Percent \\
\hline Low self-esteem $(25<)$ & 0 & 0.0 \\
\hline Average/normal self-esteem $(15-25)$ & 98 & 24.5 \\
\hline High self-esteem (>25) & 302 & 75.5 \\
\hline Total & 400 & 100.0 \\
\hline
\end{tabular}


Basing upon the scoring provided by the study of Rosenberg (1965), three-fourths of the total number of respondents have High-Level of SelfEsteem, followed by the Average/Normal Level of Self-Esteem which is almost a fourth (24.5 percent). None among the respondents have Low Level of Self-Esteem (See Table 2).

\section{School Performance of the Respondents}

The Levels of School Performance of the Respondents revealed that almost half (45.8 percent) had a Satisfactory Level. More than a third (36 percent) had Outstanding Level, while 14 percent has Very Satisfactory Academic Performance. Very small percentage belonged to Fairly Satisfactory (4.3 percent).

\section{Relationship between the profile of respondents and their level of parenting styles}

Table 3 depicts the Summary of the association between profile of the respondents in terms of age group, sex, year level, and nature of schools of the respondents against the parenting styles of their fathers and mothers.

Table 3. Summary Table on the Association between Profile of the Respondents and Parenting Styles of Both Parents

\begin{tabular}{|c|c|c|c|c|c|}
\hline Variables & $\begin{array}{l}\text { Freeman- } \\
\text { Halton Test } \\
\text { Results }\end{array}$ & Df & P-Value & Results & Decisions \\
\hline $\begin{array}{l}\text { 1. Age Group and Parenting } \\
\text { Styles of the Father }\end{array}$ & 7.533 & 9 & 0.553 & Insignificant & $\begin{array}{l}\text { Failed to reject } \\
\text { the } \mathrm{HO}\end{array}$ \\
\hline $\begin{array}{l}\text { 2. Age Group and Parenting } \\
\text { Styles of the Mother }\end{array}$ & 7.17 & 9 & 0.586 & Insignificant & $\begin{array}{c}\text { Failed to reject } \\
\text { the } \mathrm{HO}\end{array}$ \\
\hline $\begin{array}{l}\text { 3. Sex and Parenting Styles } \\
\text { of the Father }\end{array}$ & 7.717 & 3 & 0.053 & Insignificant & $\begin{array}{l}\text { Failed to reject } \\
\text { the } \mathrm{HO}\end{array}$ \\
\hline $\begin{array}{l}\text { 4. Sex and Parenting Styles } \\
\text { of the Mother }\end{array}$ & 7.683 & 3 & 0.005 & Significant & Reject theH0 \\
\hline $\begin{array}{l}\text { Year Level and Parenting } \\
\text { Styles of the Father }\end{array}$ & 3.085 & 3 & 0.38 & Insignificant & Reject theH0 \\
\hline $\begin{array}{l}\text { Year Level and Parenting } \\
\text { Styles of the Mother }\end{array}$ & 3.94 & 3 & 0.272 & Insignificant & Reject theH0 \\
\hline $\begin{array}{l}\text { Nature of School and } \\
\text { Parenting Styles of the } \\
\text { Father }\end{array}$ & 1.36 & 3 & 0.719 & Insignificant & Reject theHO \\
\hline $\begin{array}{l}\text { Nature of School and } \\
\text { Parenting Styles of the } \\
\text { Mother }\end{array}$ & 4.688 & 3 & 0.206 & Insignificant & Reject theHO \\
\hline
\end{tabular}


The Freeman-Halton Test ( $F H T=7.533, d f=9, p>0.05)$ result does not show a statistically significant association in the fathers' parenting style and the age-group of the respondents. In a similar vein, in the case of the mother's parenting style, the data failed to reject the null hypothesis.

The test of association results indicate that parenting styles of both the fathers $\left(X^{2}=7.717, d f=3, p<0.10\right)$ and the mothers $\left(X^{2}=7.683, d f=3\right.$, $p<0.05)$ are statistically associated with the sex of the respondents. These results suggest that the way fathers and mothers exercise their parenting style is linked, if not fitted, to the sex of their children.

The Chi-square test results show that the data failed to reject $\mathrm{H}_{0}$ at $p<0.05$ for the parenting styles and year level. This result means that parenting style is not associated with year level.

The Chi-square test results show no significant association between the type of school attended by the respondent and their parents' parenting style. Both insignificant results are revealed in both parenting styles, where the fathers' have shown the insignificant relationship $\left(X^{2}\right.$ Test $=1.360, d f=3$, Exact Sig. (2-sided $)=0.719)$, and the mothers' as well $\left(X^{2}\right.$ Test $=4.588$, $\mathrm{df}=3$, Exact Sig. $(2$-sided $)=0.206)$. The result means that the data failed to reject $\mathrm{H}_{\mathrm{o}}$ at $\mathrm{p}<0.05$ (See Table 3).

\section{Relationship between Profile of Respondents and their Level of Self-Esteem.}

Table 4 illustrates a summary of associations between parenting styles and self-esteem, and associations between parenting styles and school performance. The parenting styles considered separate parenting styles of mothers and fathers of the respondents.

Table 4. Summary of associations of parenting styles and self esteem; associations of parenting styles and school performance

\begin{tabular}{|c|c|c|c|c|c|}
\hline Variables & $\begin{array}{l}\text { Chi-Square } \\
\text { Test }\end{array}$ & df & P-Value & Results & Decisions \\
\hline $\begin{array}{l}\text { 1. Parenting Styles of the } \\
\text { Father and Self-Esteem }\end{array}$ & 2.927 & 3 & 0.313 & Insignificant & $\begin{array}{c}\text { Failed to reject } \\
\text { the } \mathrm{HO}\end{array}$ \\
\hline $\begin{array}{l}\text { 2. Parenting Styles of the } \\
\text { Mother and Self-Esteem }\end{array}$ & 7.611 & 3 & 0.060 & Insignificant & $\begin{array}{c}\text { Failed to reject } \\
\text { the } \mathrm{HO}\end{array}$ \\
\hline $\begin{array}{l}\text { 3. Parenting Styles of } \\
\text { the Father and School } \\
\text { Performance }\end{array}$ & 21.11 & 9 & 0.009 & Significant & Reject theHO \\
\hline $\begin{array}{l}\text { 4. Parenting Styles of } \\
\text { the Mother and School } \\
\text { Performance }\end{array}$ & 52.049 & 9 & 0.000 & Significant & Reject theHO \\
\hline
\end{tabular}


Data revealed that there is no significant degree of relationship (Freeman-Halton Test $=0.766, \mathrm{df}=3$, Exact Sig. (2-sided) $=0.876$ ) between age and Self-Esteem of the respondents in this particular study. This finding implies that age has nothing to do with the level of self-esteem of the respondents. In the study conducted titled "Stability of Self-Esteem Across the Life Span," of Trzesniewski, Donnellan, \& Robins, (2003), it was found that children have lower stability of self-esteem, the self-esteem increases across adolescent and young adulthood period and eventually declined on midlife and old age. In this particular study, it is less likely to see the significant differences in the levels of self-esteem of the respondents as all of them belonged to the adolescent period.

The data revealed that there is a statistically significant relationship $\left(X^{2}\right.$ Test $=4.379, d f=1$, Exact Sig. $(2$-sided $\left.)=0.048\right)$ between Sex and SelfEsteem of the respondents in this particular research. It means that sex have something to do with the levels of Self-Esteem of the respondents (See Table 4).

Findings in this research runs parallel to the results of the study of Robins, Hendin, \& Trzesniewski, (2001) titled "Measuring global selfesteem: Construct validation of a single-item measure and the Rosenberg Self-Esteem Scale" where the study presupposes that girls tend to have lower self-esteem compared to boys. No matter what domains were taken into consideration, differences are more likely to happen concerning appearance and athletic performance. About the development of esteemesteem, there is no major change observed when considering global perceptions. Table _ presents Chi-square test and descriptive statistics for self-esteem by year level of respondent.

Data further revealed that there is no significant statistical relationship $\left(X^{2}\right.$ Test $=1.946, d f=1$, Exact Sig. (2-sided $)=0.201$ ) between Grade Level and Self-Esteem. Hence, Grade Level has nothing to do with the SelfEsteem of the respondents.Table 18 Chi-square test and descriptive statistics for self-esteem by the nature of school where the respondents attended (See Table 4).

The Chi-Square Test revealed that there is no significant statistical relationship $\left(\mathrm{X}^{2}\right.$ Test $=0.022, \mathrm{df}=1$, Exact Sig. $(2$-sided $\left.)=0.898\right)$ between the nature of the school and the Self-Esteem of the respondents (See Table 4). 


\section{Association between parenting styles (mother and father and self- esteem of the respondents.}

Table 5 Chi-Square test and descriptive statistics for parenting style and self-esteem of the respondent.

Table 5. Parenting Styles and Self-Esteem of Respondents

\begin{tabular}{|c|c|c|c|c|c|c|c|c|c|c|}
\hline \multirow{3}{*}{$\begin{array}{l}\text { Resps' self } \\
\text { esteem } \\
\text { level }\end{array}$} & \multicolumn{10}{|c|}{ Parenting style of respondents' parents } \\
\hline & \multicolumn{5}{|c|}{ Father } & \multicolumn{5}{|c|}{ Mother } \\
\hline & $\begin{array}{l}\text { Authori- } \\
\text { tarian }\end{array}$ & $\begin{array}{l}\text { Permi- } \\
\text { ssive }\end{array}$ & $\begin{array}{l}\text { Authori- } \\
\text { tative/ } \\
\text { Flexible }\end{array}$ & $\begin{array}{l}\text { Ambi- } \\
\text { valent }\end{array}$ & $\begin{array}{l}\text { All } \\
\text { Respon- } \\
\text { dents }\end{array}$ & $\begin{array}{l}\text { Autho- } \\
\text { ritarian }\end{array}$ & $\begin{array}{l}\text { Permi- } \\
\text { ssive }\end{array}$ & $\begin{array}{l}\text { Autho- } \\
\text { ritative/ } \\
\text { Flexible }\end{array}$ & $\begin{array}{l}\text { Ambi- } \\
\text { valent }\end{array}$ & $\begin{array}{l}\text { All Re- } \\
\text { spondents }\end{array}$ \\
\hline $\begin{array}{l}\text { Average/ } \\
\text { normal }\end{array}$ & $\begin{array}{l}22.6 \\
(12)\end{array}$ & $\begin{array}{l}31.4 \\
(27)\end{array}$ & $\begin{array}{l}22.0 \\
(41)\end{array}$ & $\begin{array}{l}24.0 \\
(18)\end{array}$ & $\begin{array}{l}24.5 \\
(98)\end{array}$ & $\begin{array}{l}37.3 \\
(19)\end{array}$ & $\begin{array}{l}29.6 \\
(21)\end{array}$ & $\begin{array}{l}21.4 \\
(45)\end{array}$ & $\begin{array}{l}19.1 \\
(13)\end{array}$ & $\begin{array}{l}24.5 \\
(98)\end{array}$ \\
\hline High & $\begin{array}{l}77.4 \\
(41)\end{array}$ & $\begin{array}{l}68.6 \\
(59)\end{array}$ & $\begin{array}{l}78.0 \\
(145)\end{array}$ & $\begin{array}{l}76.0 \\
(57)\end{array}$ & $\begin{array}{l}75.5 \\
(302)\end{array}$ & $\begin{array}{l}62.7 \\
(32)\end{array}$ & $\begin{array}{l}70.4 \\
(50)\end{array}$ & $\begin{array}{l}78.6 \\
(165)\end{array}$ & $\begin{array}{l}80.9 \\
(55)\end{array}$ & $\begin{array}{l}75.5 \\
(302)\end{array}$ \\
\hline Total & $\begin{array}{l}100.0 \\
(53)\end{array}$ & $\begin{array}{l}100.0 \\
(86)\end{array}$ & $\begin{array}{l}100.0 \\
(186)\end{array}$ & $\begin{array}{l}100.0 \\
(75)\end{array}$ & $\begin{array}{l}100.0 \\
(400)\end{array}$ & $\begin{array}{l}100.0 \\
(51)\end{array}$ & $\begin{array}{l}100.0 \\
(71)\end{array}$ & $\begin{array}{l}100.0 \\
(210)\end{array}$ & $\begin{array}{l}100.0 \\
(68)\end{array}$ & $\begin{array}{l}100.0 \\
(400)\end{array}$ \\
\hline
\end{tabular}

Notes:

1. Figures shown above are in percentages, figures in parenthesis are frequency counts;

2. For father's parenting style: $X^{2}$ Test=2.927, df=3, Exact Sig. (2-sided) $=0.313$;

3. For mother's parenting style: $X^{2}$ Test $=7.611, d f=3$, Exact Sig. $(2$-sided $)=0.060$.

The Table depicts that there is no significant statistical relationship $\left(X^{2}\right.$ Test=2.927, $d f=3$, Exact Sig. (2-sided) $=0.313$ ) between the Self-Esteem of the respondents and their Fathers' Parenting Styles. The same is true with the Mothers' Parenting Style; there is no significant statistical relationship $\left(\mathrm{X}^{2}\right.$ Test $=7.611, \mathrm{df}=3$, Exact Sig. $(2$-sided $\left.)=0.060\right)$ is observed.

Literature validate that from a theoretical point of view, Adlerian theory specifies that an autocratic/authoritarian parenting style is likely to be less effective since it implies an inferior or superior relationship between parent and child as posited by the study of Milevsky, Schlechter, Netter, \& Keehn, (2007). This upbringing approach to a child fails to come up with a sense of responsibility among children. Further, permissive parenting is potentially deterrent to the development of children as it fails to provide a sense of personal achievement in their undertakings. Meanwhile, a democratic type of parenting was considered as the ideal type for psychological adjustment for a child, as behavioral compliance and psychological autonomy is seen as interdependent as asserted by Gfroerer, kern, \& Curlette, (2004). 


\section{Association between parenting styles (father and mother parenting styles and academic performance.}

Table 6 presents the Chi-square test and descriptive statistics for parenting style by school performance of respondents.

\section{Table 6. Parenting Styles and Academic Performance}

\begin{tabular}{|c|c|c|c|}
\hline \multirow{2}{*}{$\begin{array}{l}\text { Respondents' academic } \\
\text { performance }\end{array}$} & \multicolumn{2}{|c|}{ Resps' self-esteem level } & \multirow{2}{*}{ All respondents } \\
\hline & Average/normal & High & \\
\hline Outstanding & $\begin{array}{l}26.5 \\
(26)\end{array}$ & $\begin{array}{r}39.1 \\
(118)\end{array}$ & $\begin{array}{r}36.0 \\
(144)\end{array}$ \\
\hline Very Satisfactory & $\begin{array}{l}10.2 \\
(10)\end{array}$ & $\begin{array}{l}15.2 \\
(46)\end{array}$ & $\begin{array}{l}14.0 \\
(56)\end{array}$ \\
\hline Satisfactory & $\begin{array}{l}57.1 \\
(56)\end{array}$ & $\begin{array}{r}42.1 \\
(127)\end{array}$ & $\begin{array}{r}45.8 \\
(183)\end{array}$ \\
\hline Fairly Satisfactory & $\begin{array}{l}6.1 \\
(6)\end{array}$ & $\begin{array}{r}3.6 \\
(11)\end{array}$ & $\begin{array}{r}4.3 \\
(17)\end{array}$ \\
\hline Total & $\begin{array}{r}100.0 \\
(98)\end{array}$ & $\begin{array}{l}100.0 \\
(302)\end{array}$ & $\begin{array}{l}100.0 \\
(400)\end{array}$ \\
\hline
\end{tabular}

Notes:

1. Figures shown above are in percentages, figures in parenthesis are frequency counts;

2. For father's parenting style: $X^{2}$ Test $=9.322$, df $=3$, Exact Sig. $(2$-sided $)=0.024$;

Data revealed that there is a significant statistical association $\left(\mathrm{X}^{2}\right.$ Test $=9.322$, $d f=3$, Exact Sig. $(2-$ sided $)=0.024)$ between Parenting Styles and Academic Performance of the respondents. This result means parenting styles do matter to respondents academic performance. Findings of studies indicated that authoritative parenting persistently affectsthe academic performance of students. One study of Turner, Chandler, \& Heffer, (2009) titled "The influence of parenting styles, achievement motivation, and self-efficacy on academic performance in college students" that parenting styles continuously affect the respondent's academic performance even in the college level. Furthermore, research outcomes state that authoritative parenting which is defined as those parents who demand at the same time responsive to the needs of their children and set transparent expectations and clear rules to their children is associated with positive outcomes and gains in adolescents school performance and achievement. Other parenting styles included within this framework covered authoritarian and permissive parents. The tendency to 
be high on demands and low in responses on the needs of children which are under the realm of authoritarian style of parenting, even if children are performing reasonably well in their academic settings, they are more likely to be dependent, passive and conforming (Arnett, 2010; Grusec, 2002). Also, an adolescent who was brought up by permissive parents (low in demandingness and high responsiveness) are more likely to be less engaged academically and to have the tendency to be immature and irresponsible (Grusec, 2002).

\section{Degree of variance on the self-esteem of the respondents when they are grouped according to parenting styles.}

Table 7 depicts the degree of variance on the self-esteem of the respondents when grouped according to parenting styles using KruskalWallis Test.

\section{Table 7. Self-Esteem and Parenting Styles}

\begin{tabular}{lll}
\hline Parenting style & $\mathrm{n}$ & Mean Rank \\
\hline Father & 53 & 197.52 \\
Authoritarian & 86 & 183.34 \\
Permissive & 186 & 213.42 \\
Authoritative/Flexible & 75 & 190.23 \\
Ambivalent & & \\
Mother & 51 & 162.13 \\
Authoritarian & 71 & 183.87 \\
Permissive & 210 & 219.59 \\
Authoritative/Flexible & 68 & 187.69 \\
Ambivalent & &
\end{tabular}

\section{Notes:}

1. Kruskal-Wallis $H$ Test for Fathers' parenting style vs. respondent's self-esteem: $X^{2}=4.888, d f=3$, Asymp Sig=0.180;

2. Kruskal-Wallis $H$ Test for Mothers' parenting style vs. respondent's self-esteem: $X^{2}=13.770, d f=3$, Asymp Sig=0.003.

A Kruskal-Wallis test was carried out to compare the respondent's selfesteem when grouped by the parenting styles of their parents, namely: authoritarian, permissive, authoritative/flexible, and ambivalent.

The result in Table 8 shows that, in the case of fathers, no significant differences $\left(X^{2}=4.888, d f=3, p>0.05\right)$ was found among the four categories 
of parenting styles. In the case of the mothers, however, there is strong evidence of a difference ( $p$-value $<0.05$ ) between the mean ranks of at least one pair of the categories.

10. Degree of variance in the academic performance of the respondents when they are grouped according to parenting styles

Table 8 provides the Kruskal-Wallis test for the academic performance of the respondents versus parenting style.

\section{Table 8. Parenting Styles and Academic Performance}

\begin{tabular}{lll}
\hline Parenting style & $\mathrm{n}$ & Mean Rank \\
\hline Father & 53 & 193.23 \\
Authoritarian & 86 & 174.63 \\
Permissive & 186 & 225.00 \\
Authoritative/Flexible & 75 & 174.53 \\
Ambivalent & & \\
Mother & 51 & 139.25 \\
Authoritarian & 71 & 169.18 \\
Permissive & 210 & 231.66 \\
Authoritative/Flexible & 68 & 182.91 \\
Ambivalent & & \\
\hline
\end{tabular}

\section{Notes:}

1. Kruskal-Wallis H Test for Fathers' parenting style vs. respondents' academic performance: $\mathrm{X}^{2}=16.776, \mathrm{df}=3$, Asymp Sig=0.001;

2. Kruskal-Wallis H Test for Mothers' parenting style vs. respondents' academic performance: $\mathrm{X}^{2}=36.621$, df=3, Asymp Sig=0.000.

The Kruskal-Wallis test carried out to compare the respondent's academic performance when grouped by the parenting styles of their parents reveal significant variations among categories of parenting styles. There is, therefore, strong evidence that suggest that parenting style may have some bearing on how students perform at school, stronger variance on the mothers (Kruskal-Wallis $\mathrm{H}$ Test for Father's parenting style vs. respondents' academic performance: $X^{2}=16.776$, $d f=3$, Asymp Sig $=0.000$ ), compared to Fathers' (Kruskal-Wallis H Test for Fathers' parenting style vs. respondents' academic performance: $X^{2}=16.776, d f=3$, Asymp Sig=0.001).

Astudy conducted by Bean, Bush, McKenry, \& Wilson (2003) where the purpose was to examine the relationships between adolescent functioning 
(i.e., self-esteem and academic achievement) and parental support, behavioral control, and psychological control in European American and African American adolescents. Results stated that supportive behaviors of African American mothers toward their adolescent children positively predicted both self-esteem and academic achievement. The same study revealed that psychological control was significantly related to adolescent self-esteem in both the models of paternal parenting (African American and European American) and maternal parenting (African American). Also, among European American adolescents, behavioral control was a significant predictor of academic achievement and self-esteem. This study provides support for the methodological value of examining the parenting dimensions independently as opposed to combining them to form parenting styles.

On the degree of variance in the academic performance of the respondents when they are grouped according to parenting styles, there is strong evidence that suggests that parenting style may have some bearing on how students perform at school, the stronger variance on the mothers'. These findingsconnect with various studies that one predictor of school achievement is the parenting style that parents use (Steinberg, Lamborn, Darhg, Mounts, \& Dornbusch, 1994).

\section{CONCLUSIONS}

The majority of the respondents' parents utilized the authoritative parenting style. The parenting styles of the mother is dependent on the sex of the children. Parenting styles have no bearing with the self-esteem of the respondents. However, parenting styles affect the school performance of the student respondents. Several studies connect with this result as they also concluded that higher academic achievement is typically associated with lower parental authoritarianism and higher parental authoritativeness (e.g., Dornbusch, Ritter, Leiderman, Roberts, \& Fraleigh, 1987). The more authoritative the parents are, the better is the school performance of the student-respondents. Finding in the study of Steinberg, Elmen, \& Mounts (1989) indicates that authoritative parenting facilitates academic success among adolescents, the authoritative component being studied contributes for the drive to succeed, and the authoritative parenting positively impacts on achievement which is mediated partly through the effects of authoritativeness. It guides adolescents to develop a healthy sense of 
autonomy and an excellent psychological orientation to work for success. Among those whose parents are described as warm, democratic, and firm have more possibility compared to their peers to adapt positive attitudes toward, and beliefs about, their achievement, and as a consequence, they also have higher chances to perform better in school.

The self-esteem of the students affects academic performance. Extension with this type of research was conducted by Lane, Kyprianou (2004) where the study yielded that high self-esteem is associated with academic success.

The self -esteem of the students vary significantly with the different parenting styles of the mother; hence, the mother is the influencer of the self-esteem of the respondents. Academic performance varied significantly from parenting styles. Such a result is consistent with the findings of the study of Milevsky, Schlechter, Netter \& Keehn (2007) which indicated that parenting styles are related to well-being among adolescents. Authoritative parenting was observed to relate to higher self-esteem and life-satisfaction.

\section{RECOMMENDATIONS}

A need to disseminate these results to the study sites to come up with a proposal for the formulation of programmatic measures for programs on responsible parenting and improving the students' self-esteem.

A need to come up with a concrete student activities that will enhance the self-esteem and self-confidence of the students.

A need to disseminated as well these research findings to the school heads and teachers so that the Guidance and Counseling Program of the schools will be enhanced to develop the self-esteem of the adolescent respondents,

A need for a concrete Parent-Teacher and Community Association has to be mobilized so that proper cooperation and coordination of the programmatic measures on "Responsible Parenting" will be conducted; modules will be formulated by the University of Bohol regarding this concern.

\section{REFERENCES CITED}

Abedi A, Aarizi HR, Sobhaninejad M. The relationship between motivation and academic achievement of high school students in Isfahan 
with their characteristics. Scientific-Research Journal of Shahed University. 2005; 12(12): 29-38. Persian.

Al-Mutalq, H. M. (1981). Ittijahat tarbeyat eltefl fi Almamlakah Al Arabeyah Al Soudeyah [Child education in Saudi Arabia attitudes]. Riyadh, Saudi Arabia: Sciences' House for Printing and Publication.

, R. P., \& Goh, D. H. (2006). Authoritarian parenting style in Asian societies: A cluster-analytic investigation. Contemporary family therapy, 28(1), 131-151. Retrieved from https://bit.ly/2md6Ve5, (accessed last 15 April 2019).

Antonopoulou, K., Alexopoulos, D. A., \& Maridaki-Kassotaki, K. (2012). Perceptions of father parenting style, empathy, and self-esteem among Greek preadolescents. Marriage \& Family Review, 48(3), 293309.

Arnett, J. J. (1999). Adolescent storm and stress, reconsidered. American psychologist, 54(5), 317. Retrieved from https://bit.ly/2KgGZHY, (accessed last 15 February 2019).

Arnett, J. J. (2010). Adolescence and emerging adulthood (4th ed.). Upper Saddle River, NJ: Prentice Hall.

Aunola, K., Nurmi, J. E., Onatsu $\square$ Arvilommi, T., \& Pulkkinen, L. (1999). The role of parents' self-esteem, mastery $\square$ orientation and social background in their parenting styles. Scandinavian Journal of Psychology, 40(4), 307-317.

Bacus, Marites P. (2014). Parenting Styles, Self-Concept and Attitude of Students: A Causal Model on Academic Performance. International Conference on Economics, Social Sciences and Languages (ICESL'14) May 14-15, 2014 Singapore.

Baumrind, D. (1971). Current patterns of parental authority. Developmental psychology, 4(1p2), 1. Retrieved from https://bit.ly/33d5SM3, (accessed last 15 January 2019). 
Baumrind, D. (1991). The influence of parenting style on adolescent competence and substanceuse. Journal of Early Adolescence, 11,5695.

Bean, R. A., Bush, K. R., McKenry, P. C., \& Wilson, S. M. (2003). The impact of parental support, behavioral control, and psychological control on the academic achievement and self-esteem of African American and European American adolescents. Journal of Adolescent Research, 18(5), 523-541. Retrieved from https://bit.ly/2GLvW7r, (accessed last 15 January 2019).

Biabangard, E. (2005). The relationship between self-esteem, achievement motivation, academic progress in high school students in Tehran. Journal of Psychology, Faculty of Education and Psychology Azahra University, (4), 131-144.

Bogenschneider, K., 2006, Family policy matters: How policymaking affects families and what professionals can do, Mahwah, $\mathrm{NJ}$ : Lawrence Erlbaum. Retrieved from https://bit.ly/31hjRP7, (accessed last 15 February 2019).

Branden, N. (1969). The psychology of self-esteem. New York: Bantam.

Buri, J. R. (1989). Parental authority questionnaire. Journal of personality assessment, 57(1), 110-119.

Coopersmith, S. (1967). The Antecedents of Self-Esteem. San Francisco: W.H. Freeman.

Dalisay, M. F. (2014). Parenting Styles and Self-Esteem among Criminology Students of Lyceum of the Philippines University-Batangas. Batangas City.

Darling, N., \& Steinberg, L. (1993). Parenting style as context: An integrative model. Psychological bulletin, 113(3), 487. Retrieved from https://bit.ly/2RVV1zH, (accessed last 15 January 2019). 
Deshpande, A., \& Chhabriya, M. (2013). Parenting styles and its effects on adolescents' self-esteem. International Journal of Innovations in Engineering and Technology (IJIET), 310-315.

DeHart, T., Pelham, B. W., \& Tennen, H. (2006). What lies beneath: Parenting style and implicit self-esteem. Journal Of Experimental Social Psychology, 42(1), 1-17. doi:10.1016/j.jesp.2004.12.005

Diener, C. I., \& Dweck, C. S. (1978). An analysis of learned helplessness: Continuous changes in performance, strategy, and achievement cognitions following failure. Journal of personality and social psychology, 36(5), 451.

Dornbusch, S. M., Ritter, P. L., Leiderman, P. H., Roberts, D. F., \& Fraleigh, M. J. (1987). The relation of parenting style to adolescent school performance. 1987, 58, 1244-1257.

Driscoll Lucy C., (2013). Parenting Style and Self-esteem.

Dwairy, M., \& Menshar, K. E. (2006). Parenting style, individuation, and mental health of Egyptian adolescents. Journal of adolescence, 29(1), 103-117. Retrieved from https://bit.ly/2M15v1K, (accessed last 15 January 2019).

Erol, R., \& Orth, U. (2011). Self-esteem development from age 14 to 30 years: A longitudinal study. Journal Of Personality And Social Psychology, 101(3), 607-619. doi:10.1037/a0024299.

Garcia, F., \& Gracia, E. (2009). Is always authoritative the optimum parenting style? Evidence from Spanish families. Adolescence, 44(173), 101131. Retrieved from https://bit.ly/33dv0T6, (accessed last 15 February 2019).

Gilongos, N. N., \& Guarin, M. J. G. (2013). Parenting styles, children's perceivedrelationship with parents, and their social adjustment. Paper presented at the InternationalConference on Social Science Research, Penang, Malaysia. 
Glasgow, K. L., Dornbusch, S. M., Troyer, L., Steinberg, L., \& Ritter, P. L. (1997). Parenting styles, adolescents' attributions, and educational outcomes in nine heterogeneous high schools. Child development, 68(3), 507-529. Retrieved from https://bit.ly/2YGTp41, (accessed last 15 February 2019).

Graybill, D., Strawniak, M., Hunter, T., \& O'Leary, M. (1987). Effects of playing versus observing violent versus nonviolent video games on children's aggression. A Quarterly Journal of Human Behavior, 24, 1-8.

Grusec, J. E., \& Goodnow, J. J. (1994). Impact of parental discipline methods on the child's internalization of values: A reconceptualization of current points of view. Developmental Psychology, 30(1), 4-19. Retrieved from https://bit.ly/33a5E8p, (accessed last 15 January 2019).

Grusec, J. (2002). Parental socialization and children's acquisition of values. In M. Bornstein (Ed.), Handbook of parenting (Vol. 5, pp. 245281). Mahwah, NJ: Lawrence Erlbaum Associates.

Gfroerer, K., Kern, R., \& Curlette, W. (2004). Research support for individual psychology's parenting model. Journal of Individual Psychology, 61, 379-388. Retrieved from https://bit.ly/2LZPbhL, (accessed last 15 January 2019).

Hallsten, L., Rudman, A., \& Gustavsson, P. (2012). Does contingent selfesteem increase during higher education?. Self And Identity, 11(2), 223-236. doi:10.1080/15298868.2010.544872

Hosogi, M., Okada, A., Fujii, C., Noguchi, K., \& Watanabe, K. (2012). Importance and usefulness of evaluating self-esteem in children. BioPsychoSocial medicine, 6(1), 9. Retrieved from https:// bit.ly/2LZ7V18, (accessed last 15 January 2019).

Kamerman, S. B., \& Kahn, A. J. (1978). Family Policy: Government and Families in Fourteen Countries. Retrieved from https://bit.ly/2OFTq4u, (accessed last 15 February 2019). 
Kaplan, R., \& Saccuzzo, D. (2008). Psychological testing: Principles, applications, and issues. Retrieved from https://bit.ly/2ZyeZVm, (accessed last 15 February 2019).

Kordi, A., \& Baharudin, R. (2010). Parenting attitude and style and its effect on children's school achievements. International journal of psychological studies, 2(2), 217.

Lamborn, S. D., Mounts, N. S., Steinberg, L., \& Dornbusch, S. M. (1991). Patterns of competence and adjustment among adolescents from authoritative, authoritarian, indulgent, and neglectful families. Child development, 62(5), 1049-1065. Retrieved from https://bit.ly/2yCyEYy, (accessed last 15 January 2019).

Lane, J., Lane, A. M., \& Kyprianou, A. (2004). Self-efficacy, self-esteem, and their impact on academic performance. Social Behavior and Personality: an international journal, 32(3), 247-256. Retrieved from https://bit.ly/2YrSQvn, (accessed last 15 February 2019).

Lee, Y. C. (2011). A study of relationship between parenting styles and self-esteem: self-esteem's indicator-parenting styles (Doctoral dissertation, UTAR). Retrieved from https://bit.ly/2OOHRrs, (accessed last 15 July 2019).

Leung, K., Lau, S., \& Lam, W. L. (1998). Parenting styles and academic achievement: A cross-cultural study. Merrill-Palmer Quarterly (1982), 157-172. Retrieved from https://bit.ly/2ZsXCp0, (accessed last 15 February 2019).

Lightfoot, C., Cole, M., Cole, S. (2009). The development of children. New York: Worth Publishers.

Maccoby, E.E., \& Martin, J.A. (1983). Socialization in the context of the family: Parentchild interaction. In P.H. Mussen (Ed.), Handbook of child psychology. Vol. 4: Socialization, personality, and social development (pp. 1-101). New York: Wiley 
Martínez, I., \& García, J. F. (2007). Impact of parenting styles on adolescents' self-esteem and internalization of values in Spain. The Spanish Journal of Psychology, 10(2), 338-348. Retrieved from https:// bit.ly/2KdaB94, (accessed last 15 January 2019).

Martinez, I., \& Garcia, J. F. (2008). Internalization of values and self-esteem among Brazilian teenagers from authoritative, indulgent, authoritarian, and neglectful homes. ADOLESCENCE-SAN DIEGO-, 43(169), 13. Retrieved from https://bit.ly/2yAhfQd, (accessed last 15 January 2019).

Maslow A. H. (1987). Motivation and Personality (3rd ed.). New York: Harper \& Row.

Mehrafza, M. 2004. The Relationship Between Child-Rearing Practices, Creativity and Academic Achievement Among Students in High School' City of Tabriz. Iran University of Tabriz, Tabriz.

Milevsky, A., Schlechter, M., Netter, S., \& Keehn, D. (2007). Maternal and paternal parenting styles in adolescents: Associations with selfesteem, depression and life-satisfaction. Journal of child and family studies, 16(1), 39-47. Retrieved from https://bit.ly/2PuAntQ, (accessed last 15 January 2019).

Nketsia, Eric Nana (2013). Influence of Parental Styles on Adolescents Self-esteem.

Openshaw, D. K., Thomas, D. L., \& Rollins, B. C. (1984). Parental influences of adolescent self-esteem. The Journal of Early Adolescence, 4(3), 259-274. Retrieved from https://bit.ly/2YFYCci, (accessed last 15 January 2019).

Orth, U., Robins, R. W., \& Widaman, K. F. (2012). Life-span development of self-esteem and its effects on important life outcomes. Journal Of Personality And Social Psychology, 102(6), 1271-1288. doi:10.1037/ a0025558. Retrieved from https://bit.ly/2YGPSm6, (accessed last 15 January 2019). 
Orth, U., Trzesniewski, K. H., \& Robins, R. W. (2010). Self-esteem development from young adulthood to old age: A cohort-sequential longitudinal study. Journal Of Personality And Social Psychology, 98(4), 645-658. doi:10.1037/a0018769. Retrieved from https://bit. ly/2yNUDMp, (accessed last 15 January 2019).

Pilongo, L. W. E., Aparece, A. E., \& Tirol, G. O. (2013). Risky and Sexual Behaviors Among Young People of the University of Bohol. University of Bohol Multidisciplinary Research Journal, 1(1). Retrieved from https://bit.ly/2IN2XZI, (accessed last 10 February 2019).

Pomerantz, E. M., Grolnick, W. S., \& Price, C. E. (2005). The role of parents in how children approach achievement. In A. J. Elliot \& C. S. Dweck (Eds.), Handbook of Competence and Motivation. New York: Guilford Press.

Robila, M. (2014). Handbook of family policies across the globe (Vol. 10, pp. 978-1). New York, NY: Springer. Retrieved from https://bit. ly/31f6lpZ, (accessed last 15 February 2019).

Robins, R. W., Hendin, H. M., \& Trzesniewski, K. H. (2001). Measuring global self-esteem: Construct validation of a single-item measure and the Rosenberg Self-Esteem Scale. Personality and social psychology bulletin, 27(2), 151-161. Retrieved from https://bit.ly/2T591c9, (accessed last 15 January 2019).

Rodrigues, Y., Veiga, F., Fuentes, M. C., \& García, F. (2013). Parenting and adolescents' self-esteem: The Portuguese context. Revista de Psicodidáctica, 18(2), 395-416. Retrieved from https://bit. ly/2md7swB, (accessed last 10 January 2019).

Rosenberg, M. (1965). Rosenberg self-esteem scale (RSE). Acceptance and commitment therapy. Measures package, 61, 52. Retrieved from https://bit.ly/33dFzpk, (accessed last 15 January 2019).

Shamah, R. M. (2011). Parenting children of different ages: Adjusting child rearing practices. Dissertation Abstracts International, 72 . Retrieved from https://bit.ly/31dVvpF, (accessed last 15 January 2019). 
Sharma, G., \& Pandey, N. (2015). Parenting styles and its effect on selfesteem of adolescents. International Journal of Indian Psychology, 3(1), 29-39. Retrieved from https://bit.ly/2BZz37R, (accessed last 15 February 2019).

Shyny T. Y. (2017). Construction and Validation of PS-FFQ (Parenting Style Four Factor Questionnaire). Retrieved from https://bit.ly/2YLFfOS, (accessed 15 January 2019).

Spilka, B., Hood, R. W., Hunsberger, B., \& Gorsuch, R. L. (2003). The psychology of religion: An empirical approach. New York: Guilford.

Steinberg, L, Elmen, J. D, \& Mounts, N. S. (1989). Authoritative parenting, psychosocial maturity, and academic success among adolescents. Child Development, 60, 1424-1436. Retrieved from https://bit.ly/2YSZJpi, (accessed last 15 February 2019).

Steinberg, L., Lamborn, S.D., Darling, N., Mounts, N.S., \& Dornbusch, S.M. (1994). Over-Time Changes in Adjustment and Competence among Adolescence from Authoritative, Authoritarian, Indulgent, and Neglectful Families. Child Development, 65(3), 754-770. Retrieved from https://bit.ly/33bx0Lt, (accessed last 15 February 2019).

Steinberg, L., Mounts, N. S., Lamborn, S. D., \& Dornbusch, S. M. (1991). Authoritative parenting and adolescent adjustment across varied ecological niches. Journal of Research on Adolescence, 1,19- 36.

Trzesniewski, K. H., Donnellan, M. B., \& Robins, R. W. (2003). Stability of self-esteem across the life span. Journal of personality and social psychology, 84(1), 205. Retrieved from https://bit.ly/2KesQuK, (accessed last 15 January 2019).

Turner, E. A., Chandler, M., \& Heffer, R. W. (2009). The influence of parenting styles, achievement motivation, and self-efficacy on academic performance in college students. Journal of college student development, 50(3), 337-346. Retrieved from https://bit.ly/2DI1J9u, (accessed last 15 February 2019). 
Wagner, J., Lüdtke, O., Jonkmann, K., \& Trautwein, U. (2012). Cherish Yourself: Longitudinal Patterns and Conditions of Self-Esteem Change in the Transition to Young Adulthood. Journal Of Personality And Social Psychology, doi:10.1037/a0029680. Retrieved from https://bit. ly/2LYVORJ, (accessed last 15 February 2019).

Wentzel, K. R. (1994). Family functioning and academic achievement in middle school: A social-emotional perspective. Journal of Early Adolescence, 14, 268-291.

Williams, L. R., Degnan, K. A., Perez-Edgar, K. E., Henderson, H. A., Rubin, K. H., Pine, D. S., ... \& Fox, N. A. (2009). Impact of behavioral inhibition and parenting style on internalizing and externalizing problems from early childhood through adolescence. Journal of abnormal child psychology, 37(8), 1063-1075. Retrieved from https:// bit.ly/2KeD5zq, (accessed last 15 January 2019).

Yang, F., \& Liang, N. (2008). A study on the influence of early experiences on adolescents' implicit self-esteem. Psychological Science (China), 31(3), 556-561.

Yang, W., \& Zhou, W. (2008). What accounts for Chinese-American children's high academic performance: A literature review of parental influences and home environment. Gifted Education International, 24(1), 88-104. Retrieved from https://bit.ly/2YEcnUM, (accessed last 15 February 2019). 